\title{
Imagism of Chinese Poem: A Literary Study on Ezra Pound's Poetry
}

\author{
Zixi Li \\ Indiana University, USA \\ lizixi@iu.edu
}

\begin{abstract}
Imagism aims at creating poetry as art, pursuing the clarity and beauty of language, and implying personal emotions via images. While Imagism brings the most influential change in English literature, Chinese traditional poetry with its unique cultural and historical style stands out in world literature with rich emotional expression through images. This literary study compares Ezra Pound's imagist poems with classical Chinese poetry, reviewing his translations of Chinese. To scrutinize the data, a qualitative research method that covers document analysis techniques was implemented comprehensively. The research reveals that Pound's translated Chinese poems build a strong bond between the two cultures. Chinese traditional poems and Imagism poems share their love of descriptive language, a passion for accurate detail creation, joyfulness towards metaphor, analogy, personification, and other writing techniques, while they all conserve their own art form and identities
\end{abstract}

Keywords: Chinese poem, Ezra Pound, Imagism

\section{Introduction}

Three thousand and five hundred years ago, the first collection of Chinese poetry, The Book of Songs, established the style of Chinese traditional poems and the application of the power of words. Thousands of years later, Ezra Pound, one of the greatest Imagism poets, led a revolution of the beauty of words in the Western World. Imagism aims at creating poetry as art, pursuing the clarity and beauty of language, and implying personal emotions via images.

Though many differences exist, China's poetry and Imagism are still closely related. Ezra Pound's long adventure with Chinese poetry marks a linguistic and cultural crossroads for this twentieth-century American poet's cosmopolitan English and the ancient written language of classical Chinese poetry. Pound encountered Chinese poems in London in around 1909, then he was attracted to Chinese poems and translated a lot of Chinese poems later (Xie, 2015).

This research's main focus is comparing Pound's Imagist poems with classical Chinese poetry. And by considering his translations of Chinese, we can see that Pound shares many poetic techniques and goals with Chinese poetry. However, there are differences: Pound likes to break rules of traditional form in his Imagist poems, but classical Chinese poetry usually follows strict rules. Despite this difference, Pound's own translations of Chinese are often superior to other English translations, because he manages to convey the details of sound in English that are usually lost. 


\section{Research Method}

The current study implements a qualitative research method since the main data is in the narrative form. Cropley (2021) mentions that the information qualitative researchers collect in order to gain the necessary insights is obtained by means of narratives in which the people being studied communicate the way they understand the world. In this case, Chinese poems are the primary data and it is in line with Cropley (2021) says Narratives most obviously involve speaking or writing, but they can be based on other forms of communication such as diaries, literary or journalistic works, audio or videotapes, or artworks.

As for the data analysis strategy, document analysis is being used in order to gain a complete view of the poems. Document analysis itself is a form of qualitative research in which documents are interpreted by the researcher to give voice and meaning around an assessment topic (Bowen, 2009).

Basically, there are three primary types of documents (O'Leary, 2014):

a) Public Records: The official, ongoing records of an organization's activities. Examples include student transcripts, mission statements, annual reports, policy manuals, student handbooks, strategic plans, and syllabi.

b) Personal Documents: Firstperson accounts of an individual's actions, experiences, and beliefs. Examples include calendars, e-mails, scrapbooks, blogs, Facebook posts, duty logs, incident reports, reflections/journals, and newspapers.

c) Physical Evidence: Physical objects found within the study setting (often called artifacts). Examples include flyers, posters, agendas, handbooks, and training materials.

The poems that were analyzed are considered as public records since those documents are accessible publicly.

\section{Discussion}

Imagism, as its name suggests, highly focuses on creating an "image" in the reader's mind. Pound considered an image in poems as a seed that sprouts to a mature plant instead of a decorative element (Hakutani, 1992). Even though there are many different Chinese poem styles in China's long history river, the cultural style of using images to imply a poet's thesis or emotion has never changed. Chinese poets put a lot of effort into visualization. To achieve their goal, there are three concepts in Chinese most traditional poems called “赋 $(\mathrm{Fu}) ”$, “比(Bi)”, “兴 (Xing)" (Gu, 1997). "Fu" means to 
use straightforward language to describe the scenes the poet sees; "Bi" means to use analogy and metaphor to compare; "Xing" means to describe vivid images or state something related to the thesis for further explanation (Gu, 1997; Kao, 2003). Therefore, the most common feature between Imagism poems and Chinese poems is constructing a circumstance by a detailed description and implying their feelings to readers. This is a quotation from $\mathrm{Li}$ Bai's poem translated by Pound as "The River Merchant's Wife" (Sun \& Cheng, 2007):

You dragged your feet when you went out.

By the gate now, the moss is grown, the different mosses, Too deep to clear them away! The leaves fall early this autumn, in wind.

The paired butterflies are already yellow with August Over the grass in the west garden;

They hurt me. I grow older.

This piece describes that a wife is waiting for her husband to come back home from a distant business journey. These eight lines create a scene when thick moss grows, leaves fall early, and weather changes to autumn. All of those descriptions illustrate that the wife suffers from long waiting and her sorrow like the cold autumn. "Paired butterflies" is an unachievable wish for her. Weather change is a rule in nature but the poet's original version says "feeling the change hurts my heart", which illustrates her hopelessness. As you see, before the poet indicates how the wife feels in the end, he uses seven lines to describe the surroundings vividly, applying the concept "Xing". "Paired butterflies" applies both "Bi" and "Xing" styles, hoping wife and husband stay in a pair like butterflies. These characteristics are similar to Imagism poetry. In "A Girl", one of Ezra Pound's most famous poems, he uses both analogy and metaphor to describe an image of the growing tree (Pound, 2010):

The tree has entered my hands, The sap has ascended my arms, The tree has grown in my breast- 
Downward,

The branches grow out of me, like arms.

Tree you are, Moss you are, You are violets with wind above them.

A child - so high - you are, And all this is folly to the world. (p. 28)

In the first five lines, the tree is an analogy to his lover. Pound's crazy love towards "the girl" is adhesive like how a tree fastens in soil; his blood of love through his body wholly like a tree's sap flows through it; his love is increased continuously like a tree's extended branches. Pound's description brings me an image of an energetic tree. Then, in the next five lines, he uses metaphor to describe the girl as a tree, moss, violets, and a child. Pound leaves space for readers to imagine a girl that is vigorous like a tree, fresh like moss, elegant like violets, and naive like a child. Comparing Li Bai's poem and Pound's poem, obviously, they have a lot of similarities: they both have romantic themes and visual images, for example, the similar analogy usage between "The paired butterflies" and
“The tree has entered my hands", and similar descriptive language between "The leaves fall early this autumn, in wind" and "You are violets with wind above them".

Though Imagism is hugely influenced by Chinese culture, it still remains independent of its own style. An important change that the Imagism movement brings in is the free format. Classic poetry, either Chinese poetry or English traditional poetry, has comparatively strict writing rules and structures. For example, Shakespeare's sonnet form consists of fourteen lines structured as three quatrains and a couplet. The usual rhyme scheme is end rhymed as a-b-a-b, c-d-c-d, e-f-e-f, g-g (McGuire, 1987). This example, $\begin{array}{lll}\text { Shakespeare's } \quad \text { Sonnet } & 18\end{array}$ (Shakespeare, 1989), illustrates the form:

Quatrain I :

A : Shall I compare thee to a summer's day?

B : Thou art more lovely and more temperate.

A : Rough winds do shake the darling buds of May, 
B : And summer's lease hath all too short a date. (p. 1227)

This kind of formatting is subtly different between different literary movements, but in traditional poems, rhyme and line structure are crucial for a successful poem. The reason I explained the differences between English traditional poetry and Imagism is that translated Chinese poems always lack their original formatting and it's hard to show nonChinese readers how the formatting is different from Imagism. Just like English traditional poetry, Chinese poetry also has a lot of different formats with slightly different rules. Chinese poetry can be generally divided into two categories: Shi, and Ci (Hu \& Sun, 2020). Shi has the strictest rules on how many words are in one line and how many lines it should have. In addition, Shi includes Jueju and Lvshi. Further, Jueju is four lines, including Wuyan Jueju and Qiyan Jueju. "Wuyan” means each line has five words, while "Qiyan" means each line has seven words. Similarly, Lvshi is eight lines, including Wuyan Lvshi (Wu Lv) and
Qiyan Lvshi (Qi Lv). Here is a famous Chinese $\mathrm{Wu} \mathrm{Lv}$ poem with Pinyin (which is the official phonetic system for transcribing the Mandarin pronunciations of Chinese characters into the Latin alphabet) (Owen, 2015, p. 258):

国破山河在，guó pò shān hé zài

城春草木深。chéng chūn căo mù shēn

感时花溅泪, găn shí huā jiàn lèi

恨别鸟惊心。hèn bié niăo jīng xīn

烽火连三月, fēng huǒ lián sān yuè duăn

家书抵万金. jiā shū dǐ wàn jīn 白头搔更短, bái tóu sāo gèng

浑欲不胜箬。hún yù bú shèng zān

As you can see, each line includes five words and totally has eight lines. However, the rule of format is only one of the basic rules. Another very important rule is pronunciation. Additionally, the pronunciation of Chinese is also closely related to tone changes. The complicated rule of pronunciation plays a significant role in Chinese poetry for creating fluency and continuity. The poem 
above not only applies the four most basic tones but also uses "ping tone (本) \& ze tone (大) ” rules. In modern Pinyin rules, "ping tone" generally means first and second tone, while "ze tone" means third and fourth tone (In old Chinese, there is a fifth tone, which is also ze tone) (Jiang et al., 2012). Only for $\mathrm{Wu} \mathrm{Lv}$ poetry like the poem above, there are four kinds of "ping tone and ze tone" formats, which rule tones for every single word in a single line. Hence, the formatting rules Chinese traditional poetry strictly but also contributes to its beauty.

However, Imagism abandons a lot of formatting rules. Without serious formatting, Imagism poets believe metrical poetry is stiff as a metronome that is hypnotic. Pound indicates this point in his "A Few Don'ts by an Imagiste". He says "rhythmic structure should not destroy the shape of your words, or their natural sound, or their meaning" (Pound, 1913, p. 204). In other words, the rhythmic structure should be loyal to a word's actual meaning. But there is still a need of composing in the sequence of musical phrases. So imagism poets pursue inner rhyme or inner bonds through their poems. Their style looks similar to free verse. Here is Ezra Pound's "In a Station of the Metro", his most well-known poem Pound, E. (1913):

$$
\begin{aligned}
& \text { The apparition of these faces } \\
& \text { in the crowd; } \\
& \text { Petals on a wet, black bough. } \\
& \text { (p. 12) }
\end{aligned}
$$

It is a very simple and short poem. Obviously, it has no strict format at all. However, Pound provides readers with two pauses in each line. Pause is helpful for readers to build the interactions between words and their meanings. The lack of format contributes to a more precise and direct expression of the poet's feelings. Further, it sounds comparably sincere and approachable to readers. Hence, its unconstrained format distinguishes Imagism from Chinese traditional poems and also classic English poems. 
However, there is a complicated puzzle in translation - should the translated version keep its original format, and should the translated version keep its original style? Firstly, let's take a look at the original Chinese poem, 采薇, and its translated version in Zeng and $\mathrm{Su}$ (1986):

昔我往矣, 杨柳依依。

At first, when we set out, The willows were fresh and green;

今我来思, 雨雪霏霏。

Now, when we shall be returning,

The snow will be falling clouds.

行道迟迟，载饥载渴。

Long and tedious will be our marching;

We shall hunger; we shall thirst.

我心伤悲，莫知我哀。

Our hearts are wounded with grief.

And no one knows our sadness. (p. 84)

Obviously, in the original Chinese version, there are three pairs of “double words” - “依依”, “霏霏”, “迟 迟” - which displays the beauty of Chinese pronunciation. “依依” means soft, gentle, and also describes leaves dancing with the wind. “霏霏” describes hundreds of light-weighted snows dancing in the wind. “迟迟” means walking slowly. On the one hand, doubled words create rhyme and fluency, which is hardly displayed in the translated version. On the other hand, the translated version above has lost the beautiful and detailed description of the original version. Besides, the translated version is more like a translation of what the poem means instead of what the poem says. Hence, the translated version is more like prose instead of descriptive and poetic art. This poem is translated by Ezra Pound (Wang, 1965).

Willows were green when we set out, it's blowin' an'snowin' as we go down this road, muddy and slow,

hungry and thirsty and blue a doubt

(no one feels half of what we know) (p. 353)

It's interesting to see how different those translated works are. Compared with Pound's translation, the previous translation is eclipsed. 
In Chinese poems, poets never wish to over-explain the content. Instead, outstanding poems are those with visualization and somehow ambiguous themes. Pound's translation approaches the original poem more precisely. “blowin' an' sowin"”, "muddy and slow" displays the image that willow leaves are roving in the wind, the weather is getting worse, and time is elapsing. Probably, the reason that Pound is so into translating Chinese poems is the similarities of using descriptive language, metaphor, and visualization between Chinese poetry and Imagism poetry. Additionally, due to those similarities, Chinese poems translated by Imagists are loyal to the original version and maximize Chinese style.

\section{Conclusion}

Chinese traditional poetry, with its distinct cultural and historical style, stands out in international literature, whereas Imagism is one of the most important milestones in English writing. If Chinese traditional poetry is a changeable running river, the revolution of Imagism is an open gate that provides an opportunity to let the river run into the English world. Pound's translated Chinese poems build a strong bond between the two cultures. Chinese traditional poems and Imagism poems share their love of descriptive language, the passion for accurate detail creation, joyfulness towards metaphor, analogy, personification, and other writing techniques, while they all conserve their own art form and identities. Imagism is a thunder, a storm, shaking the English literature world with its distinct character, bringing new life to Chinese poetry. The magnificent vocabularies, powerful and accurate language, detailed description, and unique styles and expressions make Chinese poetry and Imagism poetry the most shining stars in literature.

\section{References}

Bowen, G. A. (2009). Document analysis as a qualitative research method. Qualitative Research Journal, 9(2), 2740. doi:10.3316/QRJo902027

Cropley, A. J. (2021). Qualitative research methods: A practice-oriented introduction for students of psychology 
and education (3rd ed). doi: 10.13140/RG.2.1.3095.6888/1

Gu, M. D. (1997). Fu-bi-xing: A metatheory of poetry-making. Chinese Literature: Essays, Articles, Reviews (CLEAR), 19, 1-22.

Hakutani, Y. (1992). Ezra Pound, Yone Noguchi, and Imagism. Modern Philology, 9o(1), 46-69.

$\mathrm{Hu}$, J., \& Sun, M. (2020). Generating Major Types of Chinese Classical Poetry in a Uniformed Framework. Archives of arXiv, Cornell University, Ithaca, NY, United States. arXiv:2003.11528 [cs.CL] Jiang, S., Zhu, L., Guo, X., Ma, W., Yang, Z., \& Dienes, Z. (2012). Unconscious structural knowledge of tonal symmetry: Tang poetry redefines limits of implicit learning. Consciousness and cognition, 21(1), 476-486.

Kao, K. S. (2003). Comparative Literature and the Ideology of Metaphor, East and West. Comparative Literature and Comparative Cultural Studies, 2, 97. McGuire, P. C. (1987). Shakespeare's Non-Shakespearean

Sonnets. Shakespeare quarterly, 38(3), 304-319.

O'Leary, Z. (2014). The essential guide to doing your research project (2nd ed.). Thousand Oaks, CA: SAGE Publications, Inc.

Owen, S. (2015). The Poetry of Du Fu. De Gruyter.

Pound, E. (1913). In a Station of the Metro. Poetry, 2(1), 12.

Pound, E. (1913). A Few Don'ts by an Imagiste. Poetry, 1(6), 200-206.

Pound, E. (2010). New selected poems and translation. New Directions Publishing.

Shakespeare, W. (1989). William Shakespeare: the complete works. Barnes \& Noble Publishing.

Sun, P. C., \& Cheng, H. K. (2007). The design of instructional multimedia in eLearning: A Media Richness Theorybased approach. Computers \& education, 49(3), 662-676.
Wang, J. C. (1965). Ezra Pound as a Translator of Classical Chinese Poetry. The Sewanee Review, 73(3), 345357.

Xie, M. (2015). Ezra Pound and the Appropriation of Chinese Poetry: Cathay, Translation, and Imagism. Routledge.

Zeng, D., Su, M. (1986). 蘇曼殊詩文選 注. China: 陕西人民出版社.

\section{Biography of the author}

Zixi Li is a hunter, walking around the world, seeking the beauty of different cultures and languages. She is particularly inspired by the connections between writing, travel, and space. Since the summer of 2008 , she has been writing creative nonfiction in Chinese. She traveled across Africa, Asia, Australia, Europe, and North America, to get inspiration through my encounters with the different environments, people, and literature.

For her, one of the most interesting and inspiring things about poem writing is how poets can condense complex meanings and feelings into images and symbols. When she studied abroad in the United States, she studied Imagist poetry, melting emotions in words, constructing images over other images in tight connection, and abandoning verbose structure. 